Article

\title{
Life Cycle Assessment of the Mesophilic, Thermophilic, and Temperature-Phased Anaerobic Digestion of Sewage Sludge
}

\author{
Iryna Lanko ${ }^{1,2, *(\mathbb{C})}$, Laura Flores ${ }^{1}\left(\mathbb{D}\right.$, Marianna Garfí $^{1}$, Vladimir Todt ${ }^{3}$, John A. Posada ${ }^{4}(\mathbb{D}$, \\ Pavel Jenicek ${ }^{2}$ and Ivet Ferrer $1, *$ (D) \\ 1 GEMMA-Group of Environmental Engineering and Microbiology, Department of Civil and Environmental \\ Engineering, Universitat Politècnica de Catalunya·BarcelonaTech, c/Jordi Girona 1-3, Building D1, \\ 08034 Barcelona, Spain; laura.flores.rosell@upc.edu (L.F.); marianna.garfi@upc.edu (M.G.) \\ 2 Department of Water Technology and Environmental Engineering, University of Chemistry and Technology, \\ Technicka, 5, 16628 Prague, Czech Republic; jenicekp@vscht.cz \\ 3 Veolia Česká Republika, a.s., Na Florenci 2116/15, Reception D, 11000 Prague, Czech Republic; \\ vladimir.todt@veolia.com \\ 4 Department of Biotechnology, Delft University of Technology, van der Maasweg 9, \\ 2629 HZ Delft, The Netherlands; J.A.PosadaDuque@tudelft.nl \\ * Correspondence: irynalanko@gmail.com (I.L.); ivet.ferrer@upc.edu (I.F.)
}

Received: 18 August 2020; Accepted: 3 November 2020; Published: 10 November 2020

check for updates

\begin{abstract}
In this study the environmental impact of the anaerobic digestion (AD) of sewage sludge within an activated sludge wastewater treatment plant (WWTP) was investigated. Three alternative AD systems (mesophilic, thermophilic, and temperature-phased anaerobic digestion (TPAD)) were compared to determine which system may have the best environmental performance. Two life cycle assessments (LCA) were performed considering: (i) the whole WWTP (for a functional unit (FU) of $1 \mathrm{~m}^{3}$ of treated wastewater), and (ii) the sludge line (SL) alone (for $\mathrm{FU}$ of $1 \mathrm{~m}^{3}$ of produced methane). The data for the LCA were obtained from previous laboratory experimental work in combination with full-scale WWTP and literature. According to the results, the WWTP with TPAD outperforms those with mesophilic and thermophilic AD in most analyzed impact categories (i.e., Human toxicity, Ionizing radiation, Metal and Fossil depletion, Agricultural land occupation, Terrestrial acidification, Freshwater eutrophication, and Ozone depletion), except for Climate change where the WWTP with mesophilic AD performed better than with TPAD by 7\%. In the case of the SL alone, the production of heat and electricity (here accounted for as avoided environmental impacts) led to credits in most of the analyzed impact categories except for Human toxicity where credits did not balance out the impacts caused by the wastewater treatment system. The best $\mathrm{AD}$ alternative was thermophilic concerning all environmental impact categories, besides Climate change and Human toxicity. Differences between both LCA results may be attributed to the FU.
\end{abstract}

Keywords: anaerobic digestion (AD); biogas; life cycle assessment (LCA); methane; waste activated sludge (WAS); wastewater treatment plant (WWTP)

\section{Introduction}

In conventional activated sludge wastewater treatment plants (WWTP), excess sludge is continuously formed at the biological reactor of the wastewater treatment line. WWTP operational expenses to handle the produced excess biological sludge, namely waste activated sludge (WAS), together with primary sludge may go up to $50 \%$ [1-3]. It has been a long time since AD was adopted as one of the most effective solutions of sewage sludge treatment in terms of sludge reduction, stabilization, 
and resource recovery [4-6]. Previously, sewage sludge was considered only as waste, and its disposal on a regular basis was quite challenging $[7,8]$. Population growth and natural resources exhaustion made it crucial to find a way out of this situation. Nowadays, sludge is considered as a source of substances that can be recovered and reused [9-11].

The zero-waste approach and circular economy paradigm change the angle at which nutrients, metals, organic matter, and other substances from WAS can be converted into valuable materials like biofuels and biofertilizers. Resource recovery processes are being widely adopted, even though recovery of certain substances, for instance, phosphorus still can be nonprofitable from the perspective of economics [12] or environmental impacts [13]. This is mostly because of the low concentration of valuable substances in the influent wastewater. However, as the world prices for phosphorus as for irreplaceable fertilizer are increasing, its recovery from sludge has become extremely important in a long-term perspective [14]. Currently, the attention is drawn to the reject water obtained after the AD process where the concentration of nutrients is significantly higher than in the influent wastewater [15]. However, the temperature regime and configuration of AD may significantly influence the nutrient concentration in the reject water and its volume [1,16,17].

$\mathrm{AD}$ is a biological process where organic matter is being biodegraded under anaerobic conditions, leading to the production of biogas, a gaseous biofuel mostly composed of methane, along with the digestate, which may be reused as biofertilizer. AD can be implemented with some variations in temperature (mesophilic (M), 35-40 ${ }^{\circ} \mathrm{C}$ and thermophilic $(\mathrm{T}), 55-70{ }^{\circ} \mathrm{C}$ ) [18] and configuration (one- and two-stage reactors) [1,19]. Normally, the AD process consists of four main stages, namely hydrolysis, acidogenesis, acetogenesis and methanogenesis, which take place in the same reactor in the case of one-stage AD. Separate functioning of the first thermophilic (hydrolytic and acidogenic) and second mesophilic (acetogenic and methanogenic) stages in two-stage AD is accomplished to overcome the drawbacks of one-stage systems [20,21].

The most widely used anaerobic digester is a mesophilic one-stage, since its operation is known as the most simple and stable [22,23]. Nevertheless, the tendency changes towards more metabolically efficient and pathogenically safe digesters such as thermophilic one-stage or temperature-phased two-stage reactors [24]. Temperature phased anaerobic digestion (TPAD) implies a combination of thermophilic and mesophilic one-stage digesters and performs with better stability than thermophilic and higher organic matter degradation rate than mesophilic, which means increased energy efficiency and better control of process parameters [21,25].

Despite the increasing interest in thermophilic and TPAD systems' application, there are few studies comparing the environmental impact of full-scale WWTP with different AD systems [26] and none concerning the comparison of the environmental impact of mesophilic, thermophilic, and TPAD systems. The environmental impact assessment would allow for defining which AD system is the most beneficial in terms of environmental protection. Thus, the objective of this study is to evaluate and compare the environmental impacts of WWTP with different AD systems (M, T, TPAD) using the life cycle assessment (LCA) methodology.

One methodological challenge that leads to variability in LCA results for multiproduct systems, such as WWTPs, is the choice of a functional unit (FU) and its effect on the ecosystem. In this study, two FUs are selected in order to demonstrate a more comprehensive picture of environmental influence of AD implemented in the sludge line alone and at the whole WWTP [27].

The LCA approach is here used not only as a standard practice to estimate the environmental burden of the technological process [22,28,29] on a micro level to compare the three AD options, but also as an alternative to build up a regulatory planning system on a meso level to increase the efficiency of project-level decision-making and to provide advice on potential improvements for the sector's management, and also to ensure the realization of strategic environmental goals [30]. 


\section{Materials and Methods}

\subsection{Anaerobic Digestion Systems}

The LCA compared three different AD systems, namely, mesophilic, thermophilic, and TPAD. Data on the operation and performance of these systems treating the same sewage sludge was gathered from three lab-scale digesters which were run during five months [31]. The substrate was thickened WAS, disintegrated through centrifugation (total solids (TS) $=71.8 \pm 3.4 \mathrm{~g} / \mathrm{L}$, volatile solids $(\mathrm{VS})=42.3 \pm 4.1 \mathrm{~g} / \mathrm{L}$, chemical oxygen demand $(\mathrm{COD})=64.1 \pm 4.1 \mathrm{~g} / \mathrm{L})$. The main features of the mesophilic, thermophilic, and TPAD lab-scale systems are shown in Table 1.

Table 1. Performance of the mesophilic, thermophilic and temperature-phased anaerobic digestion lab-scale systems. Values given as mean \pm standard deviation.

\begin{tabular}{|c|c|c|c|c|c|}
\hline & \multirow{2}{*}{$\begin{array}{l}\text { Process Variable } \\
\text { (Units) }\end{array}$} & \multirow{2}{*}{ Thermophilic } & \multirow{2}{*}{ Mesophilic } & \multicolumn{2}{|c|}{ TPAD } \\
\hline & & & & 1st Stage & 2nd Stage \\
\hline \multirow{4}{*}{$\begin{array}{l}\text { Operational } \\
\text { conditions }\end{array}$} & Temperature $\left({ }^{\circ} \mathrm{C}\right)$ & $57 \pm 1.5$ & $38 \pm 1.5$ & $57 \pm 1.5$ & $38 \pm 1.5$ \\
\hline & HRT (days) & 19 & 19 & 2 & 17 \\
\hline & $\mathrm{V}(\mathrm{L})$ & 8.45 & 8.45 & 1.0 & 8.45 \\
\hline & OLR (g VS/L·day) & 2.25 & 2.25 & \multicolumn{2}{|c|}{2.24} \\
\hline \multirow{3}{*}{$\begin{array}{l}\text { Biogas } \\
\text { production }\end{array}$} & $\begin{array}{c}\text { Methane } \\
\text { production rate } \\
\left(\mathrm{L} \mathrm{CH}_{4} / \mathrm{L} \cdot \text { day }\right)\end{array}$ & $7.8 \pm 0.5$ & $7.1 \pm 0.6$ & $2.5 \pm 0.4$ & $9.9 \pm 0.2$ \\
\hline & $\begin{array}{l}\text { Methane yield } \\
\text { (L CH} 4 / g \text { COD) }\end{array}$ & $0.17 \pm 0.02$ & $0.16 \pm 0.02$ & $0.05 \pm 0.01$ & $0.19 \pm 0.02$ \\
\hline & $\begin{array}{c}\text { Methane content in } \\
\text { biogas }\left(\% \mathrm{CH}_{4}\right)\end{array}$ & $61.7 \pm 3.1$ & $66.1 \pm 1.8$ & $58.9 \pm 5.3$ & $70.9 \pm 2.7$ \\
\hline \multirow{2}{*}{$\begin{array}{l}\text { Removal } \\
\text { efficiency }\end{array}$} & TS removal (\%) & $20.5 \pm 2.4$ & $18.5 \pm 1.7$ & \multirow{2}{*}{\multicolumn{2}{|c|}{$\begin{array}{l}24.5 \pm 2.2 \\
35.5 \pm 1.2\end{array}$}} \\
\hline & VS removal (\%) & $27.6 \pm 1.9$ & $26.0 \pm 2.6$ & & \\
\hline \multirow{5}{*}{$\begin{array}{c}\text { Effluent } \\
\text { characteristics }\end{array}$} & $\mathrm{pH}$ & $7.4 \pm 0.06$ & $7.5 \pm 0.02$ & $6.7 \pm 0.13$ & $7.6 \pm 0.02$ \\
\hline & $\mathrm{TS}(\mathrm{g} / \mathrm{L})$ & $57.1 \pm 2.4$ & $58.5 \pm 1.7$ & \multicolumn{2}{|c|}{$55.3 \pm 2.2$} \\
\hline & VS (g/L) & $30.7 \pm 1.9$ & $31.3 \pm 2.6$ & \multicolumn{2}{|c|}{$28.6 \pm 1.2$} \\
\hline & VS/TS (\%) & 53.8 & 53.5 & \multicolumn{2}{|c|}{51.7} \\
\hline & $\operatorname{COD}(\mathrm{g} / \mathrm{L})$ & $43.2 \pm 4.8$ & $44.6 \pm 3.7$ & $48.8 \pm 5.7$ & $42.1 \pm 1.2$ \\
\hline
\end{tabular}

\subsection{Life Cycle Assessment}

LCA is an analytical tool which allows to assess the environmental impacts of a product, technology, or process according to the "cradle-to-grave" approach. This time-tested technique allows not only to evaluate the potential environmental risks, but also define the life cycle stage and type of environmental impacts. The application of this method may help to improve the studied product, technology, or process by making its life cycle more friendly to the environment. LCA consists of four main steps according to ISO 14040 (2006), and ISO 14042 (2006): (i) goal and scope definition; (ii) inventory analysis; (iii) impact assessment; (iv) result interpretation.

\subsubsection{Goal and Scope Definition}

The goal of this study was to compare the potential environmental impacts of three types of AD processes: (i) mesophilic; (ii) thermophilic; (iii) TPAD systems.

To this end, two LCA cases with two different functional units (FU) were conducted: first for an activated sludge WWTP with the three different AD systems (here named as WWTP-LCA); second for the sludge line alone with the three different AD systems (here named as SL-LCA).

Since it has been reported in literature that the choice of the FU may change the overall balance of environmental impacts from harmful to beneficial and vice-versa [28], these two FUs were chosen considering the major outputs and functions of a WWTP. For the first case, the FU was $1 \mathrm{~m}^{3}$ of treated 
wastewater, as the main function of the WWTP is to treat the wastewater stream. For the second case, the FU was $1 \mathrm{~m}^{3}$ of produced methane, as one of the main functions in AD systems (also the secondary one within WWTP) is to produce energy out of the methane contained in the biogas. Methane was taken instead of biogas, as biogas might have a different content of methane depending on the AD system.

The two FUs were coupled with the system expansion approach (the alternative production of energy and fertilizers) and adopted to evaluate the environmental burden of AD at both scales, the whole WWTP (to assess the contribution of the sludge line to the whole WWTP) and the sludge line alone (to highlight the potential environmental benefits from methane production as an additional function of the system beyond the wastewater treatment). The application of two FUs would demonstrate a deeper, more comprehensive and more transparent picture of AD implementation at the sludge line and at the WWTP. Thus, applying the two FUs helps to present the environmental profile of each AD from different points of view [4,27].

For both LCAs, a period of one-year operation was considered, as it is a timescale that is long enough to assess the averaged operational parameters of any WWTP, including the fact that the construction part was not estimated in the impacts' analysis. The impacts of the construction phase were not accounted for, since the dimensioned WWTP is the same for all three scenarios and LCAs, and it would make the difference among three AD systems' exploitation less evident [4,32].

To sum up, the system's boundaries-for the first and second LCAs—consider the year-around operation of the whole WWTP with three different AD technologies (Figure 1a), and the sludge line alone with three different AD technologies (Figure 1b), respectively. Thus, three scenarios were considered in each LCA; namely mesophilic (M), thermophilic (T), and temperature-phased anaerobic digestion (TPAD).

\subsubsection{Inventory Analysis}

Inventory data for the WWTP-LCA and SL-LCA are summarized in Tables 2 and 3. Among the inputs and outputs, the flows of materials and energy resources, gaseous emissions, and solid wastes were considered. When possible, data from a full-scale facility was used, which was complemented by data gathered in the lab-scale set-up described previously (Section 2.1) [33].

Full-scale data were taken from a WWTP with thermophilic AD operated by Veolia Česká Republica, a.s. The full-scale operation was used to scale-up and validate the laboratory reactor results. The rest of the information for the mesophilic one-stage and TPAD systems was calculated based on different literature sources and benchmarking data of Veolia, a.s., as described below.

The input parameters included energy consumption, anti-bulking, anti-foaming and dewatering agent dosage, gaseous emissions from the disposed digestates, digestate amounts. Calculated parameters were energy consumption according to the literature [34], specific biogas production based on benchmarking data of Veolia, a.s., as well as anti-bulking, anti-foaming and dewatering agents' dosages.

The final digestate amount for each AD system was estimated in correspondence with the VS destruction observed in the lab-scale digesters (Table 1), which was consistent with other AD systems studied in the literature $[19,35,36]$.

Since the lab-scale set-up treated WAS and the full-scale plant used sewage sludge with $32.5 \%$ WAS, the annual biogas production was recalculated for the thermophilic scenario based on the specific biogas production of the corresponding laboratory reactor.

The heat and electricity production was calculated based on the annual biogas production and technical equipment data (efficiency of combined heat and power unit) given by Veolia, a.s.

Annual gas emissions $\left(\mathrm{CH}_{4}\right.$ and $\left.\mathrm{N}_{2} \mathrm{O}\right)$ from the wastewater treatment process and disposed digestates were estimated according to the literature $[37,38]$.

Background data (chemicals, avoided fertilizers - that are contained in the digestate and can be used in agriculture, transportation, wastewater treatment in a municipal wastewater treatment plant, solid wastes, energy provider) were taken from Ecoivent 3.1 database [33]. For all electricity 
requirements, the Czech electricity mix was considered since the full-scale WWTP is located in the Czech Republic [39] (which is composed of fossil 58.5\%, nuclear 35.3\%, solar 2.8\%, hydro $2.7 \%$, wind $-0.7 \%)$.

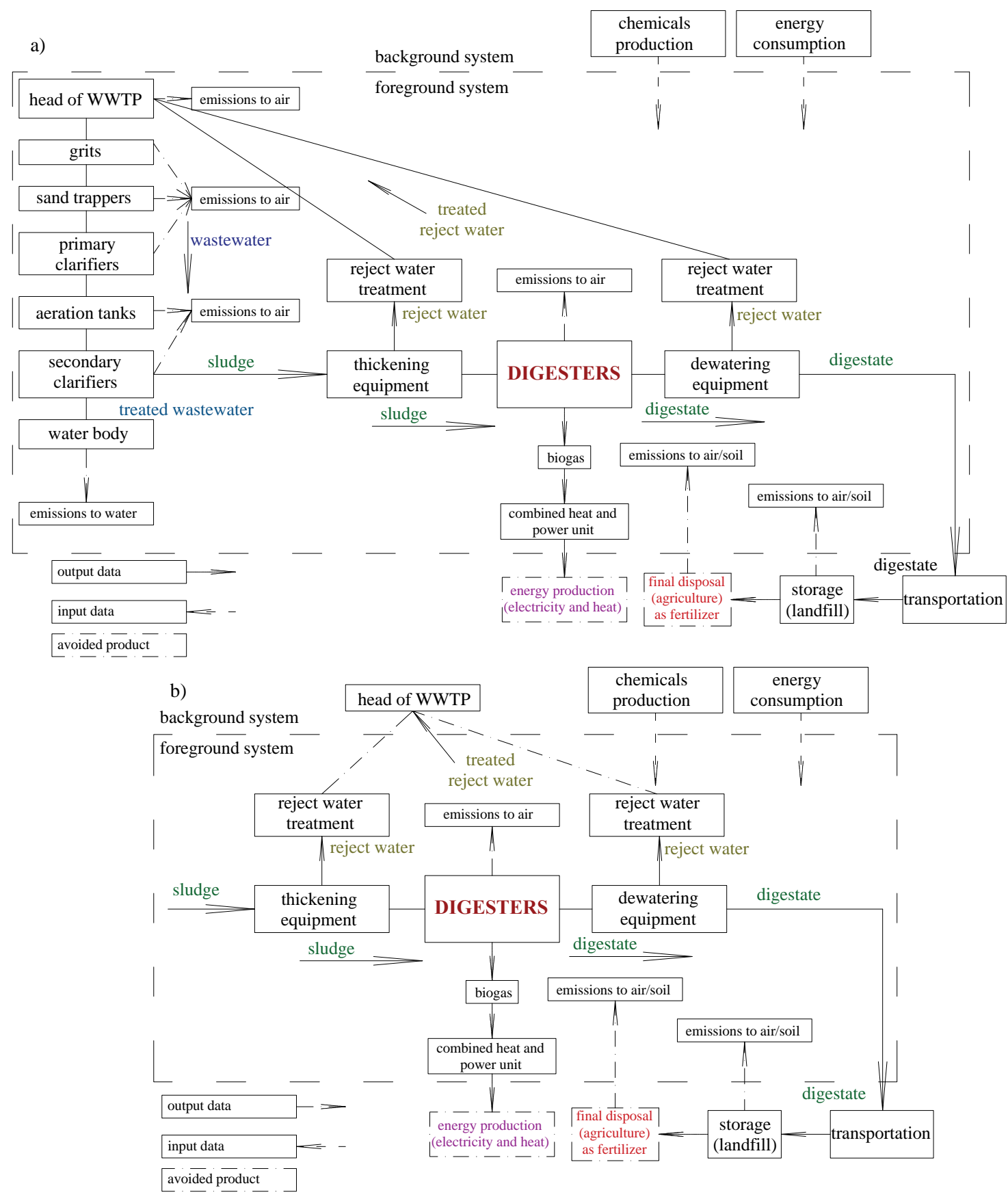

Figure 1. Flowcharts: (a) for life cycle assessment of the whole wastewater treatment plant (WWTP-LCA) and (b) for life cycle assessment of the sludge line alone (SL-LCA). 
Table 2. Inventory data for the whole WWTP LCA (FU: $1 \mathrm{~m}^{3}$ of treated wastewater).

\begin{tabular}{|c|c|c|c|c|c|c|}
\hline \multirow{2}{*}{ Type of Data } & \multirow{2}{*}{ WW/SL } & \multirow[t]{2}{*}{ Item } & \multicolumn{3}{|c|}{ Referred to FU } & \multirow[t]{2}{*}{ Unit } \\
\hline & & & $\mathbf{T}$ & $\mathbf{M}$ & TPAD & \\
\hline \multicolumn{7}{|l|}{ Input data } \\
\hline \multirow[t]{2}{*}{ Energy consumption } & WW & Only for WW & 0.32 & 0.31 & 0.3 & $\mathrm{kWh} / \mathrm{m}^{3}$ \\
\hline & SL & Only for SL & 0.1 & 0.08 & 0.09 & $\mathrm{kWh} / \mathrm{m}^{3}$ \\
\hline \multirow{5}{*}{ Reagents } & WW & Sludge anti-bulking agent & 0.05 & 0.05 & 0.05 & $\mathrm{~kg} / \mathrm{m}^{3}$ \\
\hline & \multirow{4}{*}{ SL } & Thickening agent & $1.23 \times 10^{-4}$ & $1.23 \times 10^{-4}$ & $1.23 \times 10^{-4}$ & $\mathrm{~kg} / \mathrm{m}^{3}$ \\
\hline & & Anti-foaming agent & $2.63 \times 10^{-4}$ & $5.27 \times 10^{-4}$ & $5.27 \times 10^{-4}$ & $\mathrm{~kg} / \mathrm{m}^{3}$ \\
\hline & & Dewatering agent & 0.002 & 0.001 & 0.002 & $\mathrm{~kg} / \mathrm{m}^{3}$ \\
\hline & & Chemo dezodoration agent & $1.0 \times 10^{-5}$ & $1.0 \times 10^{-5}$ & $1.0 \times 10^{-5}$ & $\mathrm{~kg} / \mathrm{m}^{3}$ \\
\hline \multicolumn{7}{|l|}{ Output data } \\
\hline \multirow{3}{*}{ Waste } & \multirow{17}{*}{ WW } & Sand & 0.001 & 0.001 & 0.001 & $\mathrm{t}^{*} \mathrm{~km} / \mathrm{m}^{3}$ \\
\hline & & Coarse waste & 0.04 & 0.04 & 0.04 & $\mathrm{~kg} / \mathrm{m}^{3}$ \\
\hline & & Coarse waste & 0.002 & 0.002 & 0.002 & $\mathrm{t}^{*} \mathrm{~km} / \mathrm{m}^{3}$ \\
\hline \multirow{7}{*}{ Wastewater air emissions } & & $\mathrm{CO}$ & 9 & 9 & 9 & $\mathrm{~g} / \mathrm{m}^{3}$ \\
\hline & & $\mathrm{SO}_{2}$ & 0.03 & 0.03 & 0.03 & $\mathrm{~g} / \mathrm{m}^{3}$ \\
\hline & & Ozone & 0.08 & 0.08 & 0.08 & $\mathrm{~g} / \mathrm{m}^{3}$ \\
\hline & & $\mathrm{N}_{2} \mathrm{O}$ & 0.05 & 0.05 & 0.05 & $\mathrm{~g} / \mathrm{m}^{3}$ \\
\hline & & $\mathrm{H}_{2} \mathrm{~S}$ & 0.0008 & 0.0008 & 0.0008 & $\mathrm{~g} / \mathrm{m}^{3}$ \\
\hline & & $\mathrm{NH}_{3}$ & 2.8 & 2.8 & 2.8 & $\mathrm{~g} / \mathrm{m}^{3}$ \\
\hline & & $\mathrm{N}_{2} \mathrm{O}$ & 1.8 & 1.81 & 1.81 & $\mathrm{~g} / \mathrm{m}^{3}$ \\
\hline \multirow{7}{*}{ Wastewater contaminants } & & $\mathrm{Pb}$ & $1.5 \times 10^{-5}$ & $1.5 \times 10^{-5}$ & $1.5 \times 10^{-5}$ & $\mathrm{~kg} / \mathrm{m}^{3}$ \\
\hline & & $\mathrm{Cd}$ & $1.2 \times 10^{-6}$ & $1.2 \times 10^{-6}$ & $1.2 \times 10^{-6}$ & $\mathrm{~kg} / \mathrm{m}^{3}$ \\
\hline & & $\mathrm{Cr}$ & $2.2 \times 10^{-6}$ & $2.2 \times 10^{-6}$ & $2.2 \times 10^{-6}$ & $\mathrm{~kg} / \mathrm{m}^{3}$ \\
\hline & & $\mathrm{Cu}$ & $2.9 \times 10^{-5}$ & $2.9 \times 10^{-5}$ & $2.9 \times 10^{-5}$ & $\mathrm{~kg} / \mathrm{m}^{3}$ \\
\hline & & $\mathrm{Ni}$ & $6.9 \times 10^{-6}$ & $6.9 \times 10^{-6}$ & $6.9 \times 10^{-6}$ & $\mathrm{~kg} / \mathrm{m}^{3}$ \\
\hline & & $\mathrm{Zn}$ & $3.2 \times 10^{-5}$ & $3.2 \times 10^{-5}$ & $3.2 \times 10^{-5}$ & $\mathrm{~kg} / \mathrm{m}^{3}$ \\
\hline & & $\mathrm{Hg}$ & $0.2 \times 10^{-7}$ & $0.2 \times 10^{-7}$ & $0.2 \times 10^{-7}$ & $\mathrm{~kg} / \mathrm{m}^{3}$ \\
\hline \multirow[t]{2}{*}{ Digestate contaminants } & \multirow{8}{*}{ SL } & $\begin{array}{l}\text { Dewatered digested sludge } \\
\text { (wet) }\end{array}$ & 0.82 & 0.86 & 0.78 & $\mathrm{~kg} / \mathrm{m}^{3}$ \\
\hline & & $\begin{array}{l}\text { Dewatered digested sludge } \\
\text { (wet) }\end{array}$ & 0.032 & 0.034 & 0.031 & $\mathrm{t}^{*} \mathrm{~km} / \mathrm{m}^{3}$ \\
\hline & & Electricity & 0.23 & 0.22 & 0.35 & $\mathrm{kWh} / \mathrm{m}^{3}$ \\
\hline Avoided products & & Heat & 0.26 & 0.25 & 0.39 & $\mathrm{kWh} / \mathrm{m}^{3}$ \\
\hline \multirow{4}{*}{ Air emissions } & & $\mathrm{H}_{2} \mathrm{~S}$ & $2.0 \times 10^{-4}$ & $2.0 \times 10^{-4}$ & $2.0 \times 10^{-4}$ & $\mathrm{~g} / \mathrm{m}^{3}$ \\
\hline & & $\mathrm{CH}_{4}$ & 0.02 & 0.02 & 0.02 & $\mathrm{~g} / \mathrm{m}^{3}$ \\
\hline & & $\mathrm{CO}_{2}$, biogenic & 28 & 28 & 28 & $\mathrm{~g} / \mathrm{m}^{3}$ \\
\hline & & $\mathrm{CO}_{2}$, not biogenic & 44 & 44 & 44 & $\mathrm{~g} / \mathrm{m}^{3}$ \\
\hline
\end{tabular}

Note: For T and TPAD, the transportation distance was $40 \mathrm{~km}$ to the sludge handling plant. According to the microbiological analyses and other sources [40], TPAD and T digestates meet the requirements of Class A biosolids. In case of $\mathrm{M}$, due to pathogenic unsafety, the digestate was additionally treated by composting before its agricultural application. Therefore, it was transported over $2 \times 40 \mathrm{~km}$ to the composting plant and back, so an additional energy consumption of $16 \mathrm{kWh} / \mathrm{t}$ of digestate for the purposes of composting was included [41]. 
Table 3. Inventory data for the sludge line LCA (FU: $1 \mathrm{~m}^{3}$ of produced methane).

\begin{tabular}{|c|c|c|c|c|c|}
\hline \multirow{2}{*}{ Type of Data } & \multirow{2}{*}{ Item } & \multicolumn{3}{|c|}{ Referred to FU } & \multirow{2}{*}{ Unit } \\
\hline & & $\mathbf{T}$ & $\mathbf{M}$ & TPAD & \\
\hline \multicolumn{6}{|l|}{ Input data } \\
\hline \multirow{2}{*}{$\begin{array}{c}\text { Energy } \\
\text { consumption }\end{array}$} & AD energy consumption & 1.32 & 1.12 & 0.79 & $\mathrm{kWh} / \mathrm{m}^{3}$ \\
\hline & $\begin{array}{l}\text { Energy consumption } \\
\text { for composting }\end{array}$ & - & 0.2 & - & $\mathrm{kWh} / \mathrm{m}^{3}$ \\
\hline \multirow{5}{*}{ Reagents } & Thickening agent & 0.002 & 0.002 & 0.001 & $\mathrm{~kg} / \mathrm{m}^{3}$ \\
\hline & Anti-foaming agent & 0.004 & 0.008 & 0.005 & $\mathrm{~kg} / \mathrm{m}^{3}$ \\
\hline & Dewatering agent & 0.027 & 0.019 & 0.014 & $\mathrm{~kg} / \mathrm{m}^{3}$ \\
\hline & Chemo dezodoration agent & $1.3 \times 10^{-4}$ & $1.4 \times 10^{-4}$ & $8.7 \times 10^{-5}$ & $\mathrm{~kg} / \mathrm{m}^{3}$ \\
\hline & Bio dezodoration agent & $3.0 \times 10^{-4}$ & $3.1 \times 10^{-4}$ & $2.0 \times 10^{-4}$ & $\mathrm{~kg} / \mathrm{m}^{3}$ \\
\hline \multicolumn{6}{|l|}{ Output data } \\
\hline Wastewater & Reject water & 0.26 & 0.26 & 0.17 & $\mathrm{~m}^{3} / \mathrm{m}^{3}$ \\
\hline \multirow{2}{*}{ Wastes } & $\begin{array}{l}\text { Dewatered digested } \\
\text { sludge (wet) }\end{array}$ & 11.3 & 12.3 & 7.1 & $\mathrm{kgDM} / \mathrm{m}^{3}$ \\
\hline & $\begin{array}{l}\text { Dewatered digested } \\
\text { sludge (wet) }\end{array}$ & 0.45 & 0.49 & 0.28 & $\mathrm{t}^{*} \mathrm{~km} / \mathrm{m}^{3}$ \\
\hline \multirow{2}{*}{$\begin{array}{l}\text { Avoided } \\
\text { products }\end{array}$} & Electricity & 3.14 & 3.14 & 3.12 & $\mathrm{kWh} / \mathrm{m}^{3}$ \\
\hline & Heat & 3.51 & 3.51 & 3.49 & $\mathrm{kWh} / \mathrm{m}^{3}$ \\
\hline \multirow{4}{*}{ Emissions } & $\mathrm{H}_{2} \mathrm{~S}$ & 0.003 & 0.003 & 0.002 & $\mathrm{~kg} / \mathrm{m}^{3}$ \\
\hline & $\mathrm{CH}_{4}$ & 0.28 & 0.29 & 0.18 & $\mathrm{~kg} / \mathrm{m}^{3}$ \\
\hline & $\mathrm{CO}_{2}$, biogenic & 386 & 402 & 253 & $\mathrm{~kg} / \mathrm{m}^{3}$ \\
\hline & $\mathrm{CO}_{2}$, not biogenic & 607 & 633 & 398 & $\mathrm{~kg} / \mathrm{m}^{3}$ \\
\hline
\end{tabular}

\subsubsection{Impact Assessment}

The LCA was performed with the software of SimaPro ${ }^{\circledR}$ 8. The potential environmental impacts were calculated by the ReCiPe midpoint method V1.12/Europe Recipe H [33].

Characterization was conducted for the following environmental impact categories: Climate change, Ozone depletion, Terrestrial acidification, Freshwater eutrophication, Human toxicity, Ionizing radiation, Agricultural land occupation, Metal depletion, and Fossil depletion [4]. The above mentioned nine environmental impact categories were selected and assessed considering their close connection with processes that take place in activated sludge WWTP with AD and that have been used in previous LCA studies [33,42].

Classification and characterization were performed as the only compulsory steps of impact assessment in terms of standards-ISO 14040 (2006) and ISO 14042 (2006).

\subsubsection{Sensitivity Analysis}

A sensitivity analysis on the digestate volume obtained from the TPAD system for both cases WWTP-LCA and SL-LCA was performed in order to take into account the influence that this parameter may have on the environmental impacts associated to digestate transport, treatment, and reuse.

The sensitivity analysis allowed to evaluate if and how the uncertainty of the assumed value in the inventory table could influence the final results. A variation of $\pm 5 \%$ of the digestate volume was set for the TPAD scenario only, according to the variability of lab data obtained by the previous studies $[19,26,35]$, and shortage of the reported data from full-scale WWTPs, since TPAD is the least spread AD system worldwide among others [43]. 
This analysis is done through the sensitivity coefficient (S) which indicates the sensitivity of a particular model output to the changes in the variable being considered. The $S$ is calculated according to the following equation [44]:

$$
\text { Sensitivity coefficient }(\mathrm{S})=\left(\frac{\text { Outputhigh }- \text { Outputlow }}{\text { Outputbaseline }}\right) /\left(\frac{\text { Inputhigh }- \text { Inputlow }}{\text { Inputbaseline }}\right)
$$

where Input is the value of the input variable (i.e., digestate amount), and Output is the value of indicator according to the correspondent impact category.

\section{Results and Discussion}

\subsection{Life Cycle Assessment}

\subsubsection{WWTP-LCA with Mesophilic, Thermophilic, or Temperature-Phased Anaerobic Digestion}

The results of the LCA for the whole WWTP (WWTP-LCA) are shown in the Figure 2. This figure includes all environmental impact categories considered in this study, and within each impact category there are three scenarios: mesophilic, thermophilic, and TPAD. For each scenario, results are shown for the whole WWTP, and separately for the wastewater treatment line and the sludge treatment line; this disaggregation of results was done to better identify the contributions of each process stage to the overall impacts. Positive values represent the environmental impacts, while negative values refer to the avoided environmental impacts.

According to the results (Figure 2), the differences among the three AD scenarios are not significantly large, however there are some trends that are discussed here. First, the wastewater treatment line would lead to larger environmental impacts than those cases where the sludge line is incorporated into the AD system. Thus, any implemented AD improves the environmental status of the WWTP mainly due to the credits obtained from the substitution of electricity generation from the fossil fuels [45]. Similar results have been reported for other LCA studies on full-scale AD plants [4,26].

In general terms, TPAD has the lowest environmental impacts, in comparison to $\mathrm{T}$ and $\mathrm{M}$, for eight out of the nine impact categories presented in Figure 2, except for Climate change. Furthermore, a one-to-one comparison between $\mathrm{T}$ and $\mathrm{M}$ shows that their calculated environmental impacts are virtually the same for five out the nine compared categories (i.e., Ionizing radiation, Agricultural land occupation, Metal depletion, Fossil depletion, and Freshwater eutrophication), and with a slightly better environmental performance (meaning lower environmental impacts) for $\mathrm{T}$ over $\mathrm{M}$ in two impact categories (i.e., Terrestrial acidification and Ozone depletion). T outperforms both M and TPAD in one category (i.e., Climate change), and has a slightly better performance than $\mathrm{M}$ in only one category (i.e., Human toxicity). 

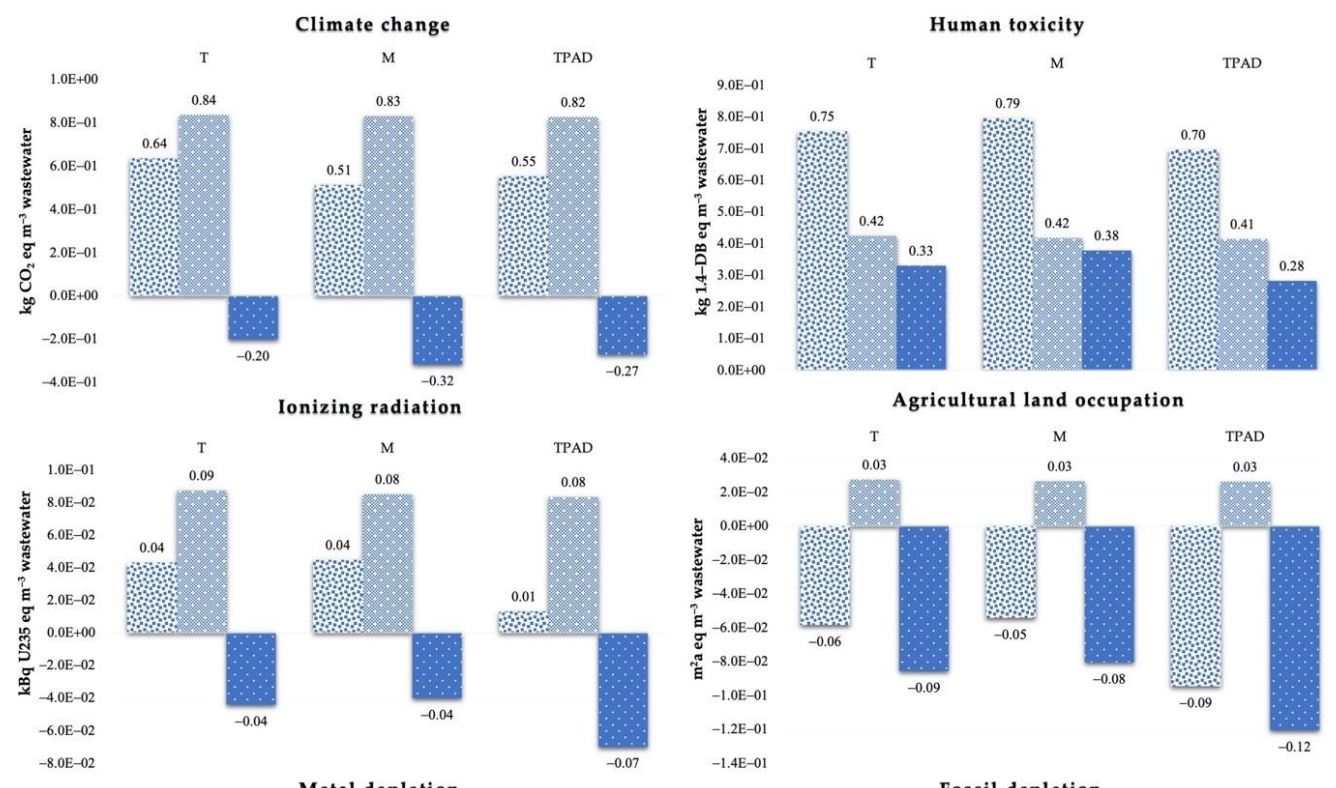

Metal depletion
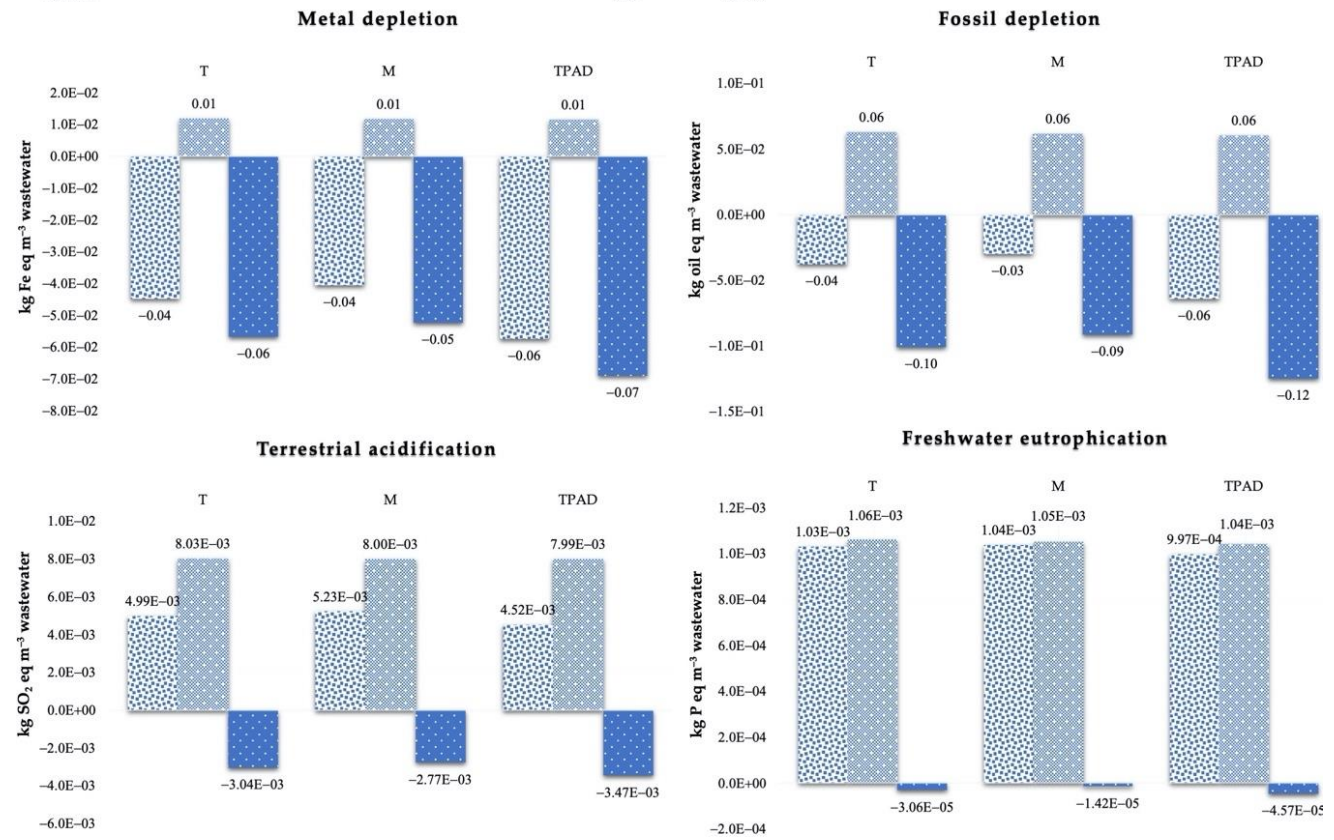

$-1.5 \mathrm{E}-0$
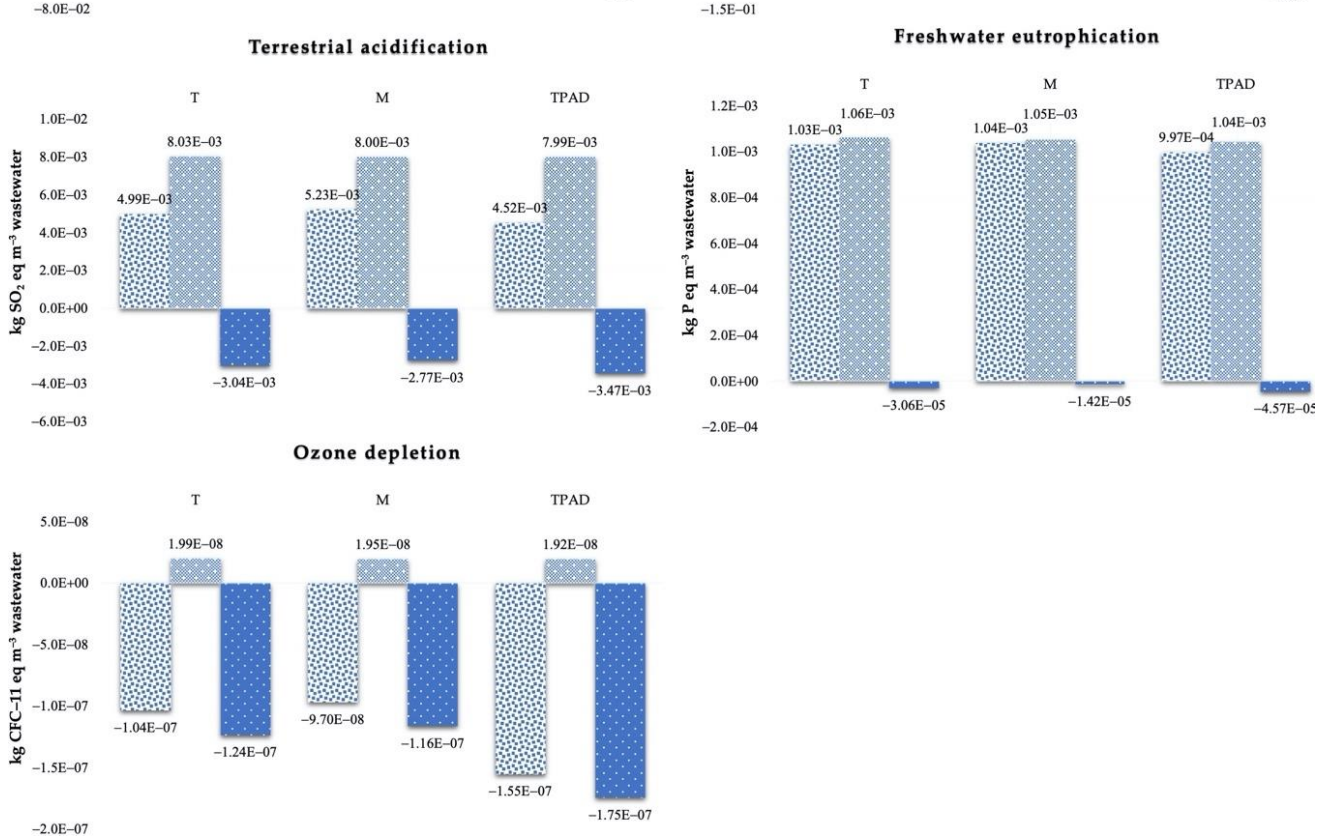

WWTP WW

Figure 2. Potential environmental impacts for the three scenarios of the whole WWTP (WWTP-LCA): Mesophilic (M), Thermophilic (T), and Temperature-Phased Anaerobic Digestion (TPAD). WWTP: wastewater treatment plant; WW: wastewater line; SL: sludge line. Results shown for the FU: $1 \mathrm{~m}^{3}$ of treated wastewater. 
In the case of Climate change, the biggest impacts are caused by the wastewater treatment line (Figure 2). Conversely, the sludge line decreases the Climate change impacts up to 38\% for $\mathrm{M}$, around $35 \%$ for TPAD, and $24 \%$ for T. Climate change is related to nonrenewable energy consumption, which is especially high in the biological reactor of activated sludge WWTP, accounting for more than $50 \%$ of the total energy consumption-Table 2 and [46]. The positive influence of sludge line mainly comes from AD which supplies with the fertilizer obtained after WAS is digested (Sludge disposal_SL) that substituted the industrial production of the fertilizer with its harmful effect through Climate change. Additionally, AD generates renewable energy out of the biogas produced as a result of the organic matter biodegradation, and counterbalances nonrenewable energy consumption that would otherwise be required to fuel the process. The highest avoided impacts on Climate change are obtained with the mesophilic digestion (M) which is $40 \%$ and $42 \%$ better than T and TPAD, respectively. These avoided impacts occur due to a type of digestate disposal (which is composting and consequent agricultural land application for M, agricultural land application alone-for T and TPAD) and to its larger amount in comparison to T and TPAD (Table 1). In terms of the energy balance, TPAD is more beneficial than $\mathrm{T}$ and $\mathrm{M}$ by more than $50 \%$ within the sludge line. The lowest total avoided impact on Climate change is obtained with the thermophilic digestion, as a consequence of the energy balance of the process, i.e., energy produced vs. energy consumed by each AD system-Figure 3.

The results of WWTP-LCA regarding all constituents are depicted in Figure 3.

With regard to the factors that contributed the most to the environmental impact of Climate change, those emissions to the air (Air emissions_WW) and from the energy demand (Electricity_WW) in the wastewater treatment line are the most significant ones (i.e., around $60 \%$ and $25 \%$, respectively, of all contributors from the wastewater treatment line). The contribution from the emissions to the air in the sludge line (Air emissions_SL) are only 5\% (Figure 3). Hence, the total environmental impact was partly compensated by land application as the final sludge disposal (Sludge disposal_SL) and energy produced from the methane (Electricity_SL) obtained during AD with the following percentage of these two factor contributions, respectively: $72 \%$ and $28 \%$ for T, $82 \%$ and $18 \%$ for $\mathrm{M}$, and $54 \%$ and $46 \%$ for TPAD. The balance of these two factors for TPAD shows better long-term performance of this AD technology.

For Human toxicity (Figure 2) the wastewater line constituents are quite similar in all scenarios, however, the absolute value of the sludge line varies: the larger negative effect to the environment is for $\mathrm{M}, 0.377 \mathrm{~kg}$ 1.4-DB eq, and the smaller one is for TPAD, $0.282 \mathrm{~kg} 1.4$-DB eq, which is almost $25 \%$ less than that of $\mathrm{M}$, and $15 \%$ less than $\mathrm{T}$. This happens due to the higher total amount of digestate produced at $\mathrm{M}$ conditions rather than at $\mathrm{T}$ or TPAD. In particular for the Human toxicity category, less than $3 \%$ of the avoided environmental impacts are given by the energy production at TPAD conditions. The main contributor to this impact category is land application (Sludge disposal_SL) due to the heavy metals and other toxic substances that are still present in the digestate (41-45\%)-Figure 3. The other major contributors are the energy consumption in the wastewater treatment line (26-29\%), followed by the water body pollution (Water pollution_WW) made by treated wastewater discharge (19-22\%) and, finally, by the different chemicals' consumption (Chemicals_WW) used at different stages of the wastewater treatment processes such as phosphorus precipitation and coagulation (all around 5\%). 


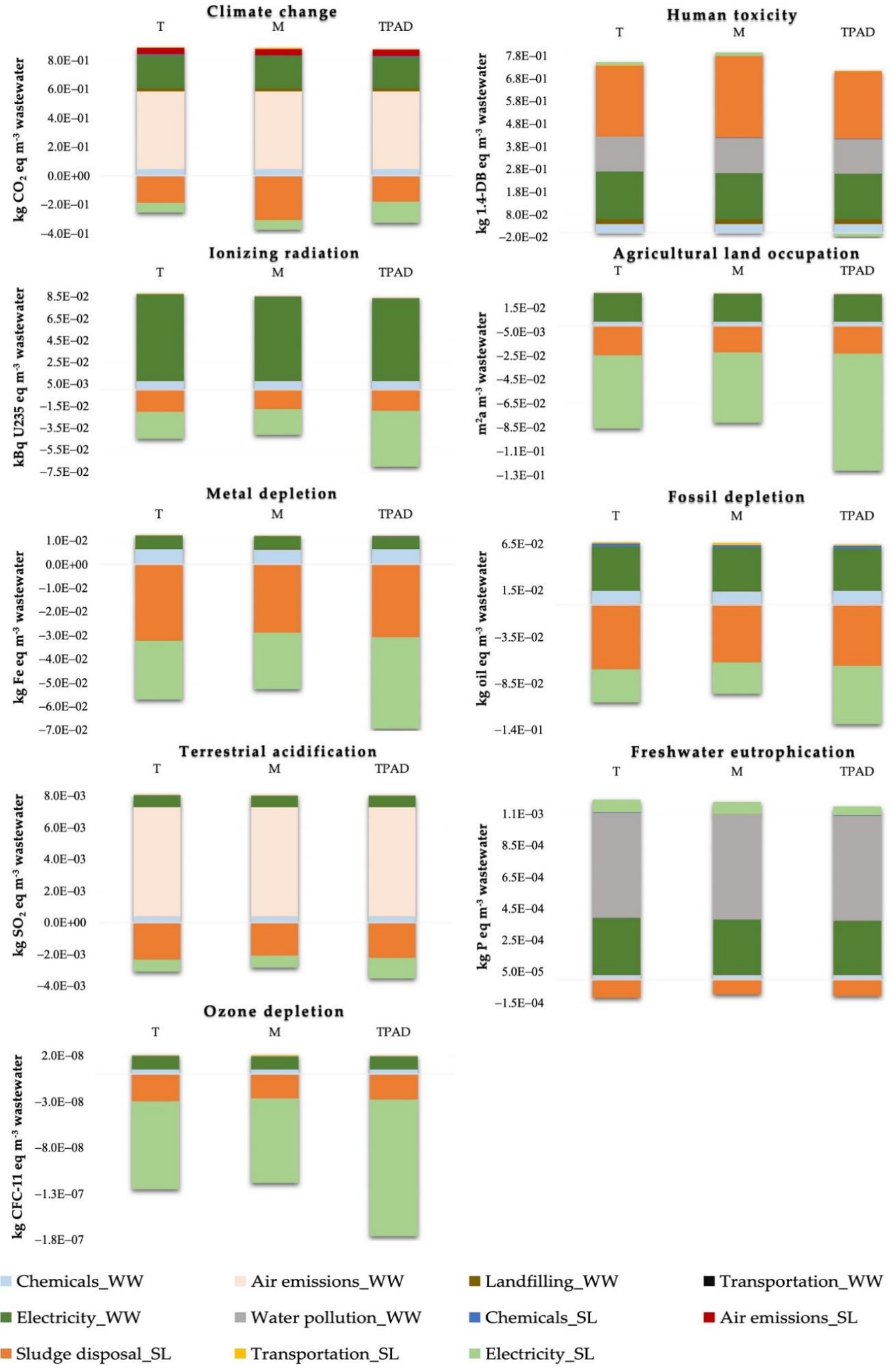

Figure 3. Contribution analysis of the potential environmental impacts for the three scenarios of both wastewater and sludge lines (WWTP-LCA): Mesophilic (M), Thermophilic (T), and Temperature-Phased Anaerobic Digestion (TPAD). Results shown for the FU: $1 \mathrm{~m}^{3}$ of wastewater treated.

In terms of the Ionizing radiation impact category, even though the absolute values for both lines are lower than $\pm 0.1 \mathrm{kBq}$ U235 eq/ $\mathrm{m}^{3}$ of treated wastewater, the avoided environmental impacts given 
by the sludge line of WWTP compensates the negative influence of wastewater treatment line for more than $40 \%$ for both T and M, and around 90\% for TPAD (Figure 2). The latter leads to a better balance of both avoided and overall environmental impacts for TPAD. The rest of the contributions are given by different chemicals' consumption (Chemicals_WW) used for wastewater treatment processes such as phosphorus precipitation and coagulation (all less than 9\%)-Figure 3. The factors that represent the avoided environmental impact are land application as the final sludge disposal (Sludge disposal_SL) and the energy production (Electricity_SL), both are from the sludge line of WWTP. The percentage contributions of them, respectively, are $45 \%$ and $55 \%$ for $\mathrm{T}, 43 \%$ and $57 \%$ for $\mathrm{M}, 27 \%$ and $73 \%$ for TPAD. For TPAD, the distribution is significantly different from $\mathrm{T}$ and $\mathrm{M}$ due to the better energy balance after AD.

In the context of other impact categories such as Agricultural land occupation, and Metal and Fossil depletion, the avoided impacts of the sludge line made mainly by land application as the final sludge disposal (Sludge disposal_SL) and energy production (Electricity_SL) completely captures the negative influence of wastewater treatment line given by energy consumption (Electricity_WW) and chemicals' consumption (Chemicals_WW)-Figure 3.

The environmental impact represented through the rest of the assessed impact categories show relatively low absolute values: $<0.0052 \mathrm{~kg} \mathrm{SO} 2 \mathrm{eq} / \mathrm{m}^{3}$ of treated wastewater for Terrestrial acidification, $<0.0011 \mathrm{~kg} \mathrm{P} \mathrm{eq} / \mathrm{m}^{3}$ of treated wastewater for Freshwater acidification, and $<-1.0 \times 10^{-7} \mathrm{~kg}$ CFC-11 eq $/ \mathrm{m}^{3}$ of treated wastewater for Ozone depletion.

Terrestrial acidification impacts are built up due to the gaseous emissions (Air emissions_WW) from the wastewater treatment line, $<10 \%$ from energy demand (Electricity), and $<5 \%$ from chemicals (Chemicals_WW) used at wastewater treatment line-Figure 3.

Freshwater eutrophication is mostly affected by water body pollution (Water pollution_WW) with a $45-50 \%$ contribution-Figure 3-and by energy consumption (Electricity_WW) with a $25 \%$ contribution from the wastewater treatment line.

Ozone depletion results are driven by the avoided environmental impacts of both the energy produced (Electricity_SL) - around 60\% for T and M, and more than 65\% for TPAD; and the land application (Sludge disposal_SL) - around 20\% for T and M, and around 15\% for TPAD (see Figure 3). These avoided impacts are significantly bigger than those caused by Electricity_WW and Chemicals_WW consumption.

Concerning the factors mainly contributing to the different environmental impact categories negatively, there are certain ones confirming their prevailing parts in the total environmental burden. In the case of WWTP-LCA, the major contributors are the gaseous emissions from the open biological step reservoirs to the air, the energy consumption for aeration tanks [47], and the water body secondary pollution given by treated wastewater discharge-see Figure 3. All of them are related to the wastewater treatment line.

For the Climate change impact category, both the gaseous emissions to the air and the energy consumption-again related to the wastewater treatment line-are the biggest contributors to the environmental burden, followed by Chemicals consumption-related to the wastewater treatment line-and the gaseous emissions to air-from the sludge line-with around 10-15\% all together.

\subsubsection{SL-LCA with Mesophilic, Thermophilic, or Temperature-Phased Anaerobic Digestion}

The LCA results of the sludge line (SL-LCA) including methane production are presented in Figure 4 using the second FU: $1 \mathrm{~m}^{3}$ of methane produced (unlike Figures 2 and 3 which use the FU: $1 \mathrm{~m}^{3}$ of wastewater treated). Figure 4 includes all environmental impact categories considered in this study, and within each impact category there are three scenarios: mesophilic, thermophilic, and TPAD. Furthermore, the different contributions from all process inputs and outputs are included for each of the three scenarios and for all categories. Positive values represent the environmental impacts, while negative values refer to the avoided environmental impacts (here considered as environmental credits). 


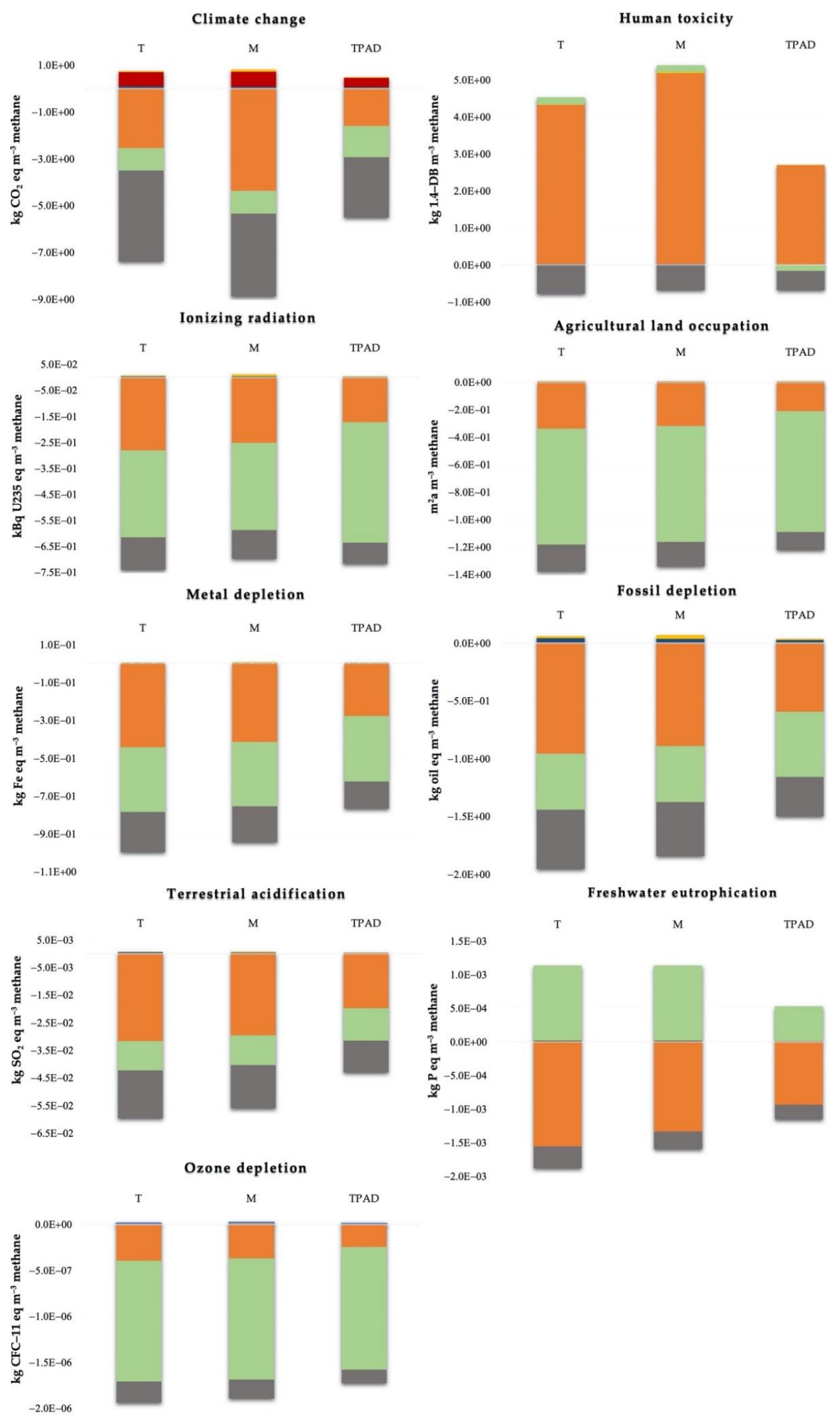

घhemicals $\square$ Air emissions $\square$ Sludge disposal $\square$ Transportation $\square$ Electricity $\square$ WWTP load

Figure 4. Contribution analysis of the potential environmental impacts for the three scenarios of the sludge line (SL-LCA): Mesophilic (M), Thermophilic (T), and Temperature-Phased Anaerobic Digestion (TPAD). Results shown for the FU: $1 \mathrm{~m}^{3}$ of methane produced. 
The aggregated SL-LCA results for the three scenarios lead to overall avoided environmental impacts in all categories with exception of Human toxicity. From the three scenarios, T outperforms M and TPAD in seven out of the nine impact categories here analyzed (except for Climate change and Human toxicity) (Figure 4). M is consistently the second best scenario in six out of the nine categories, except for Climate change (where it performs the best), and both Ionizing radiation and Human health (where it performs worse). Finally, TPAD has the lowest environmental impacts for Human health (by over 50\%), while it also has the least avoided environmental impacts for seven categories out of the nine here analyzed (Figure 4).

In all SL-LCA scenarios, the contributing factors with the largest absolute values (i.e., either potential impacts (for Human toxicity) or avoided impacts (for all the other categories)) are the final sludge disposal (starting from $15 \%$ for Ozone depletion to almost $80 \%$ for Human toxicity), energy balance (from $12 \%$ for Climate change to over $75 \%$ for Ozone depletion), and water pollution (from $11 \%$ for Human toxicity and Ionizing radiation to $22 \%$ for Fossil depletion). It is also important to highlight that the factor of gaseous emissions to the air contributes significantly in a harmful way only for Climate change (more than $80 \%$ of caused environmental impact and only less than $8 \%$ of total environmental impact) due to the digestate accumulated at the landfill [26].

In the case of specific impact categories, the avoided environmental impacts in Climate change for both $\mathrm{T}$ and $\mathrm{M}$ are larger than those of TPAD by $24 \%$ and $38 \%$, respectively-Figure 4 . The only factor causing environmental impacts on Climate change for the three scenarios are the gaseous emissions from AD installations (Air emissions). On the contrary, the avoided environmental impacts have been credited by the following factors: additional reject water treatment (WWTP load concerning each scenario: $53 \%$ for $\mathrm{T}, 40 \%$ for M, and $47 \%$ for TPAD), final sludge disposal (Sludge disposal: $34 \%$ for T, $49 \%$ for M, and $29 \%$ for TPAD) and energy production (Electricity: $13 \%$ for $\mathrm{T}, 11 \%$ for $\mathrm{M}$, and $24 \%$ for TPAD). Further minor avoided impacts are related to chemical consumption (Chemicals) (around 10\% for all AD types) and transportation (Transportation) (around 5\% for T and TPAD, and around $11 \%$ for $\mathrm{M}$ due to longer distance-a round trip-to the composting site).

In terms of Human toxicity, TPAD demonstrates the best results with the lowest environmental impacts at SL-LCA (Figure 4). The TPAD's impacts on Human toxicity are $46 \%$ lower than T, and 58\% lower than M. The most substantial contribution to Human toxicity is coming from the final sludge disposal (Sludge disposal-95\% for T, 96\% for M, and 99\% for TPAD) which makes sense as it is the agricultural land application for the $\mathrm{T}$ and TPAD scenarios and agricultural land application via composting for M scenario-Figure 4 and Table 3. The rest of the impacts on Human toxicity are mostly caused by the energy consumption (Electricity) with $4 \%$ and $3 \%$, for $\mathrm{T}$ and $\mathrm{M}$, respectively. While for TPAD, the energy balance is slightly positive, meaning that the system produces surplus energy with respect to its total consumption which leads to avoided impacts by almost $6 \%$. Hence, the TPAD scenario for SL can be considered as energy self-sufficient process and an electricity supplier. Furthermore, for Human toxicity there are some minor avoided impacts from additional reject water treatment (WWTP load-100\% for T and M and 94\% for TPAD) which is highly polluted, meaning that it can be used as an additional source for resource recovery $[15,48]$.

Interestingly, Human toxicity is the only impact category that does not result in overall avoided impacts at the sludge line. This happens due to the sufficient amounts of heavy metals and other toxic pollutants that are not completely removed during AD operation. Knowing that, T's and TPAD's digestates are considered to be pathogenically safe, and their final disposal can be a direct land application as fertilizers [35]. M digestate undergoes an additional step of composting prior to its application in agriculture. However, the gaseous emissions as well as the traces of heavy metals (Table 3) result in certain danger to the human health [9].

Looking at the Freshwater eutrophication impact category, the TPAD scenario shows both the lowest environmental impacts ( $50 \%$ lower than $\mathrm{T}$ and $\mathrm{M}$, with energy consumption-Electricity-as the main contributor) and the lowest avoided environmental impacts. In the latter case, the prevailing 
contributors are digestate usage for the agricultural land application (Sludge disposal) and water body pollution reduction (WWTP load).

The rest of the impact categories (i.e., Ionizing radiation, Agricultural land occupation, Metal and Fossil depletion, Terrestrial acidification, Freshwater eutrophication, and Ozone depletion) follow a similar pattern. For all SL-LCA scenarios, the overall result can be referred as avoided impacts, with the best results being obtained for T, followed by $\mathrm{M}$, and finally by TPAD. The main contributors are Sludge disposal and Electricity, and the WWTP load to a lower extent (with a maximum of $20 \%$ for Terrestrial acidification and lesser for other impact categories).

\subsection{Sensitivity Analysis}

The sensitivity response (i.e., the sensitivity coefficient " $\mathrm{S}$ " as described in Section 2.2.4) of all studied environmental impact categories was analyzed with respect to the assumed values for the digestate volume (with $\pm 5 \%$ of the baseline value for the TPAD scenario, i.e., 90,332 $t /$ year $>85,816 t /$ year $>81,299 t /$ year). Only the TPAD scenario was considered for sensitivity analysis due to the variability of the experimental data obtained by the previous studies $[19,26,35]$, and shortage of the reported data from full-scale WWTPs, especially considering that TPAD is the least spread AD system worldwide among others [43].

The sensitivity coefficients were analyzed considering the processing conditions of TPAD for both the WWTP and the SL alone as shown in Table 4.

Table 4. Sensitivity coefficients (S) and environmental impacts of the whole WWTP (WWTP-LCA) and SL (SL-LCA) with respect to the TPAD baseline value assumed for the digestate volume.

\begin{tabular}{|c|c|c|c|c|c|c|}
\hline $\begin{array}{c}\text { Case } \\
\text { Impact Category }\end{array}$ & \multicolumn{3}{|c|}{ WWTP } & \multicolumn{3}{|c|}{ SL } \\
\hline Human toxicity, $\mathrm{kg} 1.4-\mathrm{DB}$ eq/FU & 0.431 & 0.711 & 0.679 & 1.325 & 2.162 & 1.880 \\
\hline Ionising radiation, $\mathrm{kBq} \mathrm{U} 235 \mathrm{eq} / \mathrm{FU}$ & -1.424 & 0.012 & 0.014 & 0.241 & -0.722 & -0.704 \\
\hline Agricultural land occupation, $\mathrm{m}^{2} \mathrm{a} / \mathrm{FU}$ & 0.245 & -0.096 & -0.093 & 0.173 & -1.226 & -1.204 \\
\hline Terrestrial acidification, $\mathrm{kg} \mathrm{SO}_{2} \mathrm{eq} / \mathrm{FU}$ & -0.478 & $4.41 \times 10^{-3}$ & $4.64 \times 10^{-3}$ & 0.467 & -0.044 & -0.042 \\
\hline Freshwater eutrophication, $\mathrm{kg}$ 1.4-DB eq/FU & -0.103 & $-9.92 \times 10^{-4}$ & $-1.0 \times 10^{-3}$ & 1.504 & $-6.76 \times 10^{-4}$ & $-5.77 \times 10^{-4}$ \\
\hline Ozone depletion, kg CFC-11 eq/FU & 0.172 & $-1.57 \times 10^{-7}$ & $-1.54 \times 10^{-7}$ & 0.143 & $-1.73 \times 10^{-6}$ & $-1.71 \times 10^{-6}$ \\
\hline
\end{tabular}

Note: Sensitivity coefficients (S) are unitless; Units of each environmental impact category consider the specific FU for WWTP and SL, i.e., $1 \mathrm{~m}^{3}$ of treated wastewater and $1 \mathrm{~m}^{3}$ of produced methane, respectively. Bold numbers are for the most sensitive impact categories (with $\mathrm{S}>1.0$ ).

A positive value of the sensitivity coefficient $(S)$ refers to a straight influence of the studied parameter on the environmental results: e.g., the more sludge that is considered, the higher the (avoided) environmental impacts are. On the contrary, a negative sensitivity coefficient means an opposite influence of the studied parameter on the environmental results, it is e.g., the more sludge that is considered, the less the (avoided) environmental impacts are.

In this study, negative sensitivity coefficients are obtained only for WWTP-LCA, concerning four impact categories: Climate change, Ionizing radiation, Terrestrial acidification, and Freshwater eutrophication.

In a case of the potential environmental impacts related to the Climate change, Ionizing radiation, and Terrestrial acidification (Table 4), this behavior occurs due to an increased (proportional to the digestate volume) amount of both digestate as fertilizer substituent and energy recovered as biogas. In the case of Freshwater eutrophication, this opposite behavior occurs since an increase in the digestate volume leads to an additional amount of highly polluted reject water (that in turn needs to be further treated) generating a minor amount additional environmental impacts but that overall reduces the total avoided impacts.

On the contrary, the sensitivity coefficients for SL-LCA are positive values in all impact categories indicating a positive relation between the input variable (i.e., the assumed digestate volume) and the 
out variable (each environmental impact category). In this case, larger digestate volumes lead to the larger (either potentially caused or avoided) environmental impacts. In particular for the Human toxicity category, impacts are higher with the increase in the digestate volume (due to the proportional increase in the present pollutants in the digestate), while all the other categories included in Table 4 result in larger avoided environmental impacts with the increment in the digestate volume (due to the production of the avoided products such as fertilizers and electricity).

The most sensitive environmental impact categories in terms of $\pm 5 \%$ variation in the digestate amount are, at SL-LCA, Human toxicity and Freshwater eutrophication, as $\mathrm{S}$ is positive and higher than 1.0.

The digestate amount variation of $+5 \%$ increases the environmental burden of Human toxicity by $6.5 \%$ from the baseline value at SL-LCA. At WWTP-LCA, the digestate amount of $\pm 5 \%$ had the influence of around $2.0 \%$ referring to the baseline value. It is also important to mention that the Human toxicity impact category is the only one with positive sensitivity coefficients at both LCAs, and for SL-LCA the sensitivity coefficient is higher than 1.0. Hence, it is important to mention that such sensitivity behavior of the Human toxicity category reveals that the major environmental concern based the variability of the digestate amounts would be on this impact category.

For Freshwater eutrophication at SL-LCA, the avoided environmental impacts increase by over $7.0 \%$ along with the increment in the digestate amount applied in agriculture as a fertilizer. At WWTP-LCA, the sensitivity coefficient at this impact category is negative and lower than 1.0, and can be neglected.

At the WWTP-LCA, the rest of the impact categories (i.e., apart from the ones with negative sensitivity coefficient) result in $\mathrm{S}$ values lower than 1.0. The sensitivity coefficient values higher than 0.5 are for the impact categories Metal and Fossil depletion. These two impact categories are affected by $2.5 \%$ to $5 \%$, respectively (Table 4 ), and they refer to overall avoided environmental impacts. Furthermore, the sensitivity coefficients for Metal and Fossil depletion at WWTP-LCA are higher than those at SL-LCA. A reason for such a difference is the contribution in the energy balance (Electricity_WW) at WW line (Tables 3 and 4). The absolute values of avoided environmental impacts at $\pm 5 \%$ of digestate are essentially higher at SL-LCA than at WWTP-LCA for Metal depletion (on over 92\%) and for Fossil depletion (on over 95\%) due to the energy consumption at the WW line concerning both impact categories.

In general terms, it can be said that the WW line has a higher harmful effect on the environment than SL line itself, and the larger its scale is, the larger the potential environmental impacts will be, contrary to the SL line.

Other general trends from the sensitivity analysis are that the sensitivity gives a clear overview that AD, namely TPAD, affects the environment mainly due to the toxic substances' content and air emissions derived from the digestate, which are proportional to its volume. The digestate production affects the environment negatively by the contribution to Human toxicity due to the final sludge disposal (Sludge disposal) coming from the SL line which relates to both WWTP-LCA and SL-LCA (Figures 3 and 4). At the same time, digestate production has also a positive effect given by resource (fertilizer) and energy (electricity and heat) recovery (Sludge disposal and Electricity, respectively) and also due to the additional reject water treatment (WWTP load) derived from the SL line (Figure 4).

Therefore, the impact categories of Human toxicity, Metal and Fossil depletion which are directly related to the produced digestate amount are of major attention for these types of processes. Considering the case of the TPAD scenario, it can also be said that $\pm 5 \%$ of digestate production does not affect most of the (avoided) environmental impacts. Only three environmental impact categories have $S>1.0$, namely: Human toxicity (SL-LCA), Ionizing radiation (WWTP-LCA), and Freshwater eutrophication (SL-LCA). These $S$ values, bigger than 1.0, are strongly related to several contributing factors such as energy consumption (WWTP-LCA), final sludge disposal, and reject water treatment (SL-LCA)-Figures 3 and 4, and Table 4. Hence, these findings of the sensitivity analysis should be considered and taken into account for future designs of WWTPs and AD systems. 
Based on the sensitivity analysis performed, it can be said that the main factor that contributes to the environmental impact through Human toxicity impact category is digestate quality (pathogenic safety, presence of the toxic substances, and gaseous emissions) and its amount. Therefore, by considering and changing the final digestate disposal, the total environmental impact can be reduced.

\section{Conclusions}

In this study, a comparative LCA analysis was carried out to evaluate the environmental impacts of three alternative AD processes (mesophilic, thermophilic, and TPAD) used for sludge treatment in activated sludge WWTP. The environmental burden was evaluated at two scales, namely the whole WWTP (to assess the contribution of the sludge line to the whole WWTP)—with a FU of $1 \mathrm{~m}^{3}$ treated wastewater-and the sludge line alone (to highlight the potential environmental benefits from methane production as an additional function of the system beyond the wastewater treatment) -with a FU of $1 \mathrm{~m}^{3}$ produced methane.

In the WWTP-LCA, five (Climate change, Human toxicity, Ionizing radiation, Terrestrial acidification, and Freshwater eutrophication) out of the nine environmental impact categories analyzed showed potential environmental impacts. The rest of the environmental impact categories (Agricultural land occupation, Metal and Fossil depletion, Ozone depletion) showed avoided environmental impacts, since the WW line led to potential environmental impacts in all impact categories, while the SL line led to avoided environmental impacts for most environmental impact categories (except for Human toxicity). Among all scenarios, the WWTP with TPAD outperformed those with mesophilic and thermophilic $\mathrm{AD}$ in all the environmental impact categories, besides Climate change.

The SL-LCA showed mostly avoided impacts, being the highest for thermophilic AD, followed by mesophilic AD and TPAD, except for Climate change where mesophilic AD was the most beneficial. The only potential environmental impact was Human toxicity, being the lowest for TPAD.

Differences between both LCA results may be attributed to the FU.

In addition, it can be also concluded that such products as nutrients and energy recovered from the AD systems and incorporated into the sludge treatment create an amount of credits that make the whole WWTP more environmentally friendly.

Author Contributions: Conceptualization, P.J., I.F. and M.G.; Methodology, J.A.P., M.G. and I.F.; software, I.L. and L.F.; validation, M.G., V.T., P.J. and I.F.; formal analysis, I.L.; investigation, I.L.; resources, V.T. and P.J.; data curation, I.L. and L.F.; Writing—original draft preparation, I.L.; Writing—review and editing, J.A.P., I.F. and P.J.; supervision, P.J. and I.F.; project administration, P.J.; funding acquisition, P.J. and I.F. All authors have read and agreed to the published version of the manuscript.

Funding: The research was funded by the European Union's Horizon 2020 research and innovation programme under the Marie Skłodowska-Curie grant agreement No 676070. This communication reflects only the authors' views and the Research Executive Agency of the EU is not responsible for any use that may be made regarding the information it contains.

Acknowledgments: I.F. and M.G. are grateful to the Government of Catalonia (Consolidated Research Group 2017 SGR 1029). M.G. acknowledges the Spanish Ministry of Economy and Competitiveness (RYC-2016-20059).

Conflicts of Interest: The authors declare no conflict of interest. The funders had no role in the design of the study; in the collection, analyses, or interpretation of data; in the writing of the manuscript, or in the decision to publish the results. 


\section{Abbreviations}

$\begin{array}{ll}\text { AD } & \text { anaerobic digestion } \\ \text { COD } & \text { chemical oxygen demand } \\ \text { HRT } & \text { hydraulic retention time } \\ \text { LCA } & \text { life cycle assessment } \\ \text { M } & \text { mesophilic } \\ \text { OLR } & \text { organic loading rate } \\ \text { SL } & \text { sludge treatment line } \\ \text { SL-LCA } & \text { LCA performed within the boundaries of the sludge line } \\ \text { T } & \text { thermophilic } \\ \text { TPAD } & \text { temperature-phased anaerobic digestion } \\ \text { TS } & \text { total solids } \\ \text { V } & \text { reactor working volume } \\ \text { VS } & \text { volatile solids } \\ \text { WAS } & \text { waste activated sludge } \\ \text { WW } & \text { wastewater treatment line } \\ \text { WWTP } & \text { wastewater treatment plant } \\ \text { WWTP-LCA } & \text { LCA performed within the boundaries of the whole wastewater treatment plant }\end{array}$

\section{References}

1. Leite, W.R.M.; Gottardo, M.; Pavan, P.; Filho, P.B.; Bolzonella, D. Performance and energy aspects of single and two phase thermophilic anaerobic digestion of waste activated sludge. Renew. Energy 2016, 86, 1324-1331. [CrossRef]

2. Yang, P.; Li, D.; Zhang, W.; Wang, N.; Yang, Z.; Wang, D.; Ma, T. Flocculation-dewatering behavior of waste activated sludge particles under chemical conditioning with inorganic polymer flocculant: Effects of typical sludge properties. Chemosphere 2019, 218, 930-940. [CrossRef]

3. Wei, H.; Gao, B.; Ren, J.; Li, A.; Yang, H. Coagulation/flocculation in dewatering of sludge: A review. Water Res. 2018, 143, 608-631. [CrossRef]

4. Lamnatou, C.; Nicolaï, R.; Chemisana, D.; Cristofari, C.; Cancellieri, D. Biogas production by means of an anaerobic-digestion plant in France: LCA of greenhouse-gas emissions and other environmental indicators. Sci. Total. Environ. 2019, 670, 1226-1239. [CrossRef]

5. Rajendran, K.; Murthy, G.S. Techno-economic and life cycle assessments of anaerobic digestion-A review. Biocatal. Agric. Biotechnol. 2019, 20, 101207. [CrossRef]

6. Wainaina, S.; Awasthi, M.K.; Sarsaiya, S.; Chen, H.; Singh, E.; Kumar, A.; Ravindran, B.; Awasthi, S.K.; Liu, T.; Duan, Y.; et al. Resource recovery and circular economy from organic solid waste using aerobic and anaerobic digestion technologies. Bioresour. Technol. 2020, 301, 122778. [CrossRef]

7. Zhang, J.; Liu, J.; Wang, Y.; Yu, D.; Sui, Q.; Wang, R.; Chen, M.; Tong, J.; Wei, Y. Profiles and drivers of antibiotic resistance genes distribution in one-stage and two-stage sludge anaerobic digestion based on microwave- $\mathrm{H}_{2} \mathrm{O}_{2}$ pretreatment. Bioresour. Technol. 2017, 241, 573-581. [CrossRef] [PubMed]

8. Wei, W.; Wu, L.; Liu, X.; Chen, Z.; Hao, Q.; Wang, D.; Liu, Y.; Peng, L.; Ni, B.-J. How does synthetic musks affect methane production from the anaerobic digestion of waste activated sludge? Sci. Total. Environ. 2020, 713, 136594. [CrossRef] [PubMed]

9. Hao, X.; Wang, X.; Liu, R.; Li, S.; Van Loosdrecht, M.C.; Jiang, H. Environmental impacts of resource recovery from wastewater treatment plants. Water Res. 2019, 160, 268-277. [CrossRef]

10. Meena, R.A.A.; Kannah, R.Y.; Sindhu, J.; Ragavi, J.; Kumar, G.; Gunasekaran, M.; Banu, J.R. Trends and resource recovery in biological wastewater treatment system. Bioresour. Technol. Rep. 2019, 7, 100235. [CrossRef]

11. Mesjasz-Lech, A. Reverse logistics of municipal solid waste-Towards zero waste cities. Transp. Res. Procedia 2019, 39, 320-332. [CrossRef]

12. Ye, Y.; Ngo, H.H.; Guo, W.; Liu, Y.; Li, J.; Liu, Y.; Zhang, X.; Jia, H. Insight into chemical phosphate recovery from municipal wastewater. Sci. Total Environ. 2017, 576, 159-171. [CrossRef] [PubMed] 
13. Pradel, M.; Aissani, L. Environmental impacts of phosphorus recovery from a "product" Life Cycle Assessment perspective: Allocating burdens of wastewater treatment in the production of sludge-based phosphate fertilizers. Sci. Total Environ. 2019, 656, 55-69. [CrossRef] [PubMed]

14. Cordell, D.; Rosemarin, A.; Schröder, J.; Smit, A. Towards global phosphorus security: A systems framework for phosphorus recovery and reuse options. Chemosphere 2011, 84, 747-758. [CrossRef] [PubMed]

15. Khan, E.U.; Nordberg, A. Membrane distillation process for concentration of nutrients and water recovery from digestate reject water. Sep. Purif. Technol. 2018, 206, 90-98. [CrossRef]

16. De Vrieze, J.; Smet, D.; Klok, J.; Colsen, J.; Angenent, L.T.; Vlaeminck, S. Thermophilic sludge digestion improves energy balance and nutrient recovery potential in full-scale municipal wastewater treatment plants. Bioresour. Technol. 2016, 218, 1237-1245. [CrossRef]

17. Ruffino, B.; Cerutti, A.; Campo, G.; Scibilia, G.; Lorenzi, E.; Zanetti, M. Thermophilic vs. mesophilic anaerobic digestion of waste activated sludge: Modelling and energy balance for its applicability at a full scale WWTP. Renew. Energy 2020, 156, 235-248. [CrossRef]

18. Lin, R.; Cheng, J.; Ding, L.; Murphy, J.D. Improved efficiency of anaerobic digestion through direct interspecies electron transfer at mesophilic and thermophilic temperature ranges. Chem. Eng. J. 2018, 350, 681-691. [CrossRef]

19. Micolucci, F.; Gottardo, M.; Valentino, F.; Cavinato, C.; Bolzonella, D. Pilot scale comparison of single and double-stage thermophilic anaerobic digestion of food waste. J. Clean. Prod. 2018, 171, 1376-1385. [CrossRef]

20. Cao, Z.; Hülsemann, B.; Wüst, D.; Illi, L.; Oechsner, H.; Kruse, A. Valorization of maize silage digestate from two-stage anaerobic digestion by hydrothermal carbonization. Energy Convers. Manag. 2020, 222, 113218. [CrossRef]

21. Srisowmeya, G.; Chakravarthy, M.; Devi, G.N. Critical considerations in two-stage anaerobic digestion of food waste-A review. Renew. Sustain. Energy Rev. 2020, 119, 109587. [CrossRef]

22. Zhang, K.; Gu, J.; Wang, X.; Yin, Y.; Zhang, X.; Zhang, R.; Tuo, X.; Zhang, L. Variations in the denitrifying microbial community and functional genes during mesophilic and thermophilic anaerobic digestion of cattle manure. Sci. Total Environ. 2018, 634, 501-508. [CrossRef] [PubMed]

23. Kim, M.; Ahn, Y.-H.; Speece, R. Comparative process stability and efficiency of anaerobic digestion; mesophilic vs. thermophilic. Water Res. 2002, 36, 4369-4385. [CrossRef]

24. Song, Y.-C.; Kwon, S.-J.; Woo, J.-H. Mesophilic and thermophilic temperature co-phase anaerobic digestion compared with single-stage mesophilic- and thermophilic digestion of sewage sludge. Water Res. 2004, 38, 1653-1662. [CrossRef]

25. Fernández-Rodríguez, J.; Pérez, M.; Romero, L.I. Semicontinuous Temperature-Phased Anaerobic Digestion (TPAD) of Organic Fraction of Municipal Solid Waste (OFMSW). Comparison with single-stage processes. Chem. Eng. J. 2016, 285, 409-416. [CrossRef]

26. Yu, Q.; Li, H.; Deng, Z.; Liao, X.; Liu, S.; Liu, J. Comparative assessment on two full-scale food waste treatment plants with different anaerobic digestion processes. J. Clean. Prod. 2020, 263, 121625. [CrossRef]

27. Sills, D.L.; Van Doren, L.G.; Beal, C.; Raynor, E. The effect of functional unit and co-product handling methods on life cycle assessment of an algal biorefinery. Algal Res. 2020, 46, 101770. [CrossRef]

28. Li, H.; Jin, C.; Zhang, Z.; O'Hara, I.M.; Mundree, S. Environmental and economic life cycle assessment of energy recovery from sewage sludge through different anaerobic digestion pathways. Energy 2017, 126, 649-657. [CrossRef]

29. Li, H.; Feng, K. Life cycle assessment of the environmental impacts and energy efficiency of an integration of sludge anaerobic digestion and pyrolysis. J. Clean. Prod. 2018, 195, 476-485. [CrossRef]

30. Zhang, B.; Su, S.; Zhu, Y.; Li, X. An LCA-based environmental impact assessment model for regulatory planning. Environ. Impact Assess. Rev. 2020, 83, 106406. [CrossRef]

31. Lanko, I.; Jenicek, P. Anaerobic Sludge Digestion: Single System Versus Two-Stage One; UCT Prague: Dejvice, Czech Republic, 2019; p. 1.

32. Timonen, K.; Sinkko, T.; Luostarinen, S.; Tampio, E.; Joensuu, K. LCA of anaerobic digestion: Emission allocation for energy and digestate. J. Clean. Prod. 2019, 235, 1567-1579. [CrossRef]

33. Garfi, M.; Flores, L.; Ferrer, I. Life Cycle Assessment of wastewater treatment systems for small communities: Activated sludge, constructed wetlands and high rate algal ponds. J. Clean. Prod. 2017, 161, 211-219. [CrossRef] 
34. Ferrer, I.; Serrano, E.; Ponsá, S.; Vázquez, F.; Font, X. Enhancement of Thermophilic Anaerobic Sludge Digestion by $70{ }^{\circ} \mathrm{C}$ Pre-Treatment: Energy Considerations. J. Residuals Sci. Technol. 2009, 6, 11-18.

35. Riau, V.; De La Rubia, M.Á; Pérez, M. Temperature-phased anaerobic digestion (TPAD) to obtain class A biosolids: A semi-continuous study. Bioresour. Technol. 2010, 101, 2706-2712. [CrossRef] [PubMed]

36. Courtens, E.N.P.; Vlaeminck, S.E.; Vilchez-Vargas, R.; Verliefde, A.; Jauregui, R.; Pieper, D.H.; Boon, N. Trade-off between mesophilic and thermophilic denitrification: Rates vs. sludge production, settleability and stability. Water Res. 2014, 63, 234-244. [CrossRef]

37. Daelman, M.R.; Van Voorthuizen, E.M.; Van Dongen, L.G.J.M.; Volcke, E.I.P.; Van Loosdrecht, M.C.M. Methane and nitrous oxide emissions from municipal wastewater treatment-Results from a long-term study. Water Sci. Technol. 2013, 67, 2350-2355. [CrossRef]

38. Willén, A.; Rodhe, L.; Pell, M.; Jönsson, H. Nitrous oxide and methane emissions during storage of dewatered digested sewage sludge. J. Environ. Manag. 2016, 184, 560-568. [CrossRef]

39. GlobalPetrolPrices.com. Available online: https://ru.globalpetrolprices.com/energy_mix.php?countryId=188 (accessed on 9 October 2020).

40. Akgul, D.; Cella, M.A.; Eskicioglu, C. Influences of low-energy input microwave and ultrasonic pretreatments on single-stage and temperature-phased anaerobic digestion (TPAD) of municipal wastewater sludge. Energy 2017, 123, 271-282. [CrossRef]

41. Li, Y.; Han, Y.; Zhang, Y.; Fang, Y.; Li, S.; Li, G.; Luo, W. Factors affecting gaseous emissions, maturity, and energy efficiency in composting of livestock manure digestate. Sci. Total Environ. 2020, 731, 139157. [CrossRef]

42. Corominas, L.; Foley, J.; Guest, J.S.; Hospido, A.; Larsen, H.F.; Morera, S.; Shaw, A. Life cycle assessment applied to wastewater treatment: State of the art. Water Res. 2013, 47, 5480-5492. [CrossRef]

43. Massanet-Nicolau, J.; Dinsdale, R.M.; Guwy, A.; Shipley, G. Utilising biohydrogen to increase methane production, energy yields and process efficiency via two stage anaerobic digestion of grass. Bioresour. Technol. 2015, 189, 379-383. [CrossRef] [PubMed]

44. Dixon, A.; Simon, M.; Burkitt, T. Assessing the environmental impact of two options for small-scale wastewater treatment: Comparing a reedbed and an aerated biological filter using a life cycle approach. Ecol. Eng. 2003, 20, 297-308. [CrossRef]

45. Bacenetti, J.; Fiala, M. Carbon footprint of electricity from anaerobic digestion plants in Italy. Environ. Eng. Manag. J. 2015, 14, 1495-1502. [CrossRef]

46. Lizarralde, I.; Fernández-Arévalo, T.; Beltrán, S.; Ayesa, E.; Grau, P. Validation of a multi-phase plant-wide model for the description of the aeration process in a WWTP. Water Res. 2018, 129, 305-318. [CrossRef] [PubMed]

47. Uggetti, E.; Ferrer, I.; Molist, J.; García, J. Technical, economic and environmental assessment of sludge treatment wetlands. Water Res. 2011, 45, 573-582. [CrossRef]

48. Quist-Jensen, C.A.; Sørensen, M.J.; Svenstrup, A.; Scarpa, L.; Carlsen, T.S.; Jensen, H.C.; Wybrandt, L.; Christensen, M.L. Membrane crystallization for phosphorus recovery and ammonia stripping from reject water from sludge dewatering process. Desalination 2018, 440, 156-160. [CrossRef]

Publisher's Note: MDPI stays neutral with regard to jurisdictional claims in published maps and institutional affiliations.

(C) 2020 by the authors. Licensee MDPI, Basel, Switzerland. This article is an open access article distributed under the terms and conditions of the Creative Commons Attribution (CC BY) license (http://creativecommons.org/licenses/by/4.0/). 